\title{
BADAI SITOKIN COVID-19
}

\author{
Sumihar M. R. Pasaribu \\ Departemen Biokimia Fakultas Kedokteran, Universitas Methodist Indonesia, Medan, Indonesia \\ Email: sumiharpasaribu@gmail.com
}

DOI: https://doi.org/10.46880/methoda.Vol11No3.pp224-230

\begin{abstract}
COVID-19 is a rapidly spreading global threat that has been declared a pandemic by WHO. COVID-19 is transmitted through droplets or direct contact and infects the respiratory tract causing pneumonia in most cases and acute respiratory distress syndrome (ARDS) in about $15 \%$ of cases. Deaths in COVID-19 patients have been linked to so-called "cytokine storms" caused by the virus. Overproduction of proinflammatory cytokines leads to worsening of ARDS and extensive tissue damage resulting in multi-organ failure and death. Suppressing cytokines during the management of COVID-19 patients can increase survival rates and reduce mortality.
\end{abstract}

Keyword: COVID-19, Cytokine Storms, ARDS, IL-6.

\begin{abstract}
ABSTRAK
COVID-19 adalah ancaman global yang menyebar dengan cepat yang telah dinyatakan sebagai pandemi oleh WHO. COVID-19 ditularkan melalui tetesan atau kontak langsung dan menginfeksi saluran pernapasan yang mengakibatkan pneumonia pada sebagian besar kasus dan sindrom gangguan pernapasan akut (ARDS) pada sekitar 15\% kasus. Kematian pada pasien COVID-19 telah dikaitkan dengan apa yang disebut "badai sitokin" yang disebabkan oleh virus. Produksi sitokin proinflamasi yang berlebihan menyebabkan perburukan ARDS dan kerusakan jaringan luas yang mengakibatkan kegagalan multiorgan dan kematian. Menekan sitokin selama pengelolaan pasien COVID-19 dapat meningkatkan tingkat kelangsungan hidup dan mengurangi kematian.
\end{abstract}

Kata Kunci: COVID-19, Badai Sitokin, ARDS, IL-6.

\section{PENDAHULUAN}

Pada Desember 2019, dilaporkan terjadi wabah kasus pneumonia di Wuhan, China. Wabah itu terkait dengan Pasar makanan Huanan. Virus 2019-nCoV diisolasi pada 7 Januari 2020 dan diidentifikasi sebagai penyebab wabah (WHO, 2020a). Virus 2019nCoV dengan cepat menyebar ke seluruh China dan banyak negara lain dan menyebabkan wabah global yang berkembang pesat. Pada 11 Februari 2020, WHO menamakan penyakit tersebut COVID-19, kependekan dari "coronavirus disease 2019" (WHO, 2020b) dan pada 12 Maret 2020 jumlah total kasus terkonfirmasi COVID19 mencapai 125.260 secara global dengan 80.981 kasus di China dan 44.279 di luar China dan COVID-19 dinyatakan sebagai pandemi oleh WHO (WHO, 2020d). COVID-19 telah dikonfirmasi pada 5.404.512 orang secara global dengan kematian mencapai 343.514 dengan moralitas 6,4\% sampai pada 26 Mei 2020, Amerika Serikat memiliki jumlah kasus terkonfirmasi tertinggi (1.618.757 kasus) (WHO, 2020c).

\section{DISKUSI}

Penularan dan Manifestasi Klinis COVID-19

COVID-19 disebabkan oleh SARS-CoV-2 yang termasuk dalam subfamili betacoronavirus. Coronavirus adalah virus RNA besar beruntai tunggal positif. Meskipun data pertama yang tersedia tentang COVID-19 
menunjukkan kemungkinan penularan dari hewan ke manusia melalui hewan liar di Pasar makanan laut Huanan di Wuhan (Guo et al., 2020; P. Zhou et al., 2020), data dan studi epidemiologi, setelah itu, semakin menunjukkan bahwa virus menular dari manusia ke manusia, melalui tetesan atau kontak langsung, dengan pelaporan bahwa individu yang tidak melakukan kontak langsung dengan pasar makanan laut Huanan didiagnosis dengan COVID- 19 dan dengan kasus sekunder yang terjadi di rumah sakit di antara petugas kesehatan yang memiliki kontak ekstensif dengan pasien COVID-19. Virus dipastikan menyebar melalui droplet pernapasan dari batuk atau bersin (Zhao et al., 2020) dengan kemampuan inang untuk menularkan infeksi saat tanpa gejala (Bai et al., 2020). Studi sekarang juga mengusulkan kemungkinan penularan virus secara feco-oral (Gu, Han, \& Wang, 2020).

Pasien COVID-19 sebagian besar adalah orang dewasa $>18$ tahun dengan dominasi lakilaki, anggapan bahwa pediatri tidak terkena infeksi kemudian berubah dengan kasus yang dikonfirmasi terjadi di pediatri di Cina dan di seluruh dunia (Dong et al., 2020; Le et al., 2020), meskipun kematian masih lebih banyak pada kelompok dewasa di atas usia 65 tahun. Orang dewasa dengan penyakit kardiovaskular yang sudah ada sebelumnya, penyakit pernapasan, penyakit endokrin, penderita diabetes, atau orang dewasa dengan gangguan kekebalan tetap menjadi yang paling terpapar komplikasi serius COVID-19 (F. Zhou et al., 2020).

Meskipun banyak pasien COVID-19 tetap tanpa gejala, beberapa pasien mengalami pneumonia dan $10 \%$ kasus memerlukan ventilasi mekanis dan perawatan di ICU. Pasien biasanya datang dengan gejala demam, batuk kering, sesak napas, sakit kepala, malaise, nyeri otot, dan tulang, sakit tenggorokan, kebingungan, batuk produktif, hemoptisis, diare, mual, dan nyeri dada (N. Chen et al., 2020). Perkembangan ke pneumonia didokumentasikan oleh temuan radiologis dan biasanya terjadi 1-2 minggu setelah awal gejala. Tanda-tanda pneumonia termasuk penurunan saturasi oksigen, penurunan gas darah, kekeruhan kaca multi-fokal, atau konsolidasi tidak merata/segmental pada rontgen dada atau CT. Pasien yang terlambat atau memburuk pasien dirawat di rumah sakit biasanya menderita akut respiratory distress syndrome (ARDS), kegagalan pernafasan akut, cedera ginjal akut, dan kegagalan multi-organ (Lai, Shih, Ko, Tang, \& Hsueh, 2020; Li et al., 2020).

\section{Gambaran Laboratorium COVID-19}

Gambaran darah lengkap pasien COVID-19 biasanya menunjukkan limfopenia dengan atau tanpa leukopenia total. Jumlah limfosit $<1,0 \times 10$ 9/L telah dikaitkan dengan penyakit parah (Singhal, 2020). Sebuah penelitian baru-baru ini melaporkan bahwa kasus COVID-19 yang parah cenderung memiliki rasio neutrofil terhadap limfosit (NLR) yang lebih tinggi. NLR dihitung dari gambaran darah rutin dengan membagi jumlah neutrofil absolut dengan jumlah limfosit absolut dan menunjukkan status inflamasi pasien secara keseluruhan. Peningkatan NLR merupakan faktor risiko kematian tidak hanya di penyakit menular tetapi juga dalam keganasan, akut sindrom koroner, perdarahan intraserebral, polymyositis, dan dermatomyostis (Liu et al., 2020). Jumlah trombosit biasanya normal atau sedikit menurun. CRP (C-reaktif Protein) dan laju sedimentasi eritrosit biasanya meningkat sementara kadar prokalsitonin normal dan peningkatan prokalsitonin biasanya menunjukkan infeksi bakteri sekunder. Laktat dehidrogenase, feritin, D-dimer, dan peningkatan kreatin kinase dikaitkan dengan penyakit yang parah. Peningkatan kadar kreatinin atau enzim hati (ALT dan AST) terjadi pada kasus rumit yang berkembang menjadi kegagalan multi-organ (Singhal, 2020).

\section{Profil Sitokin dan Badai Sitokin}

COVID-19 menimbulkan ancaman yang meningkat bagi manusia dengan tingkat kematian 6,4\% (WHO, 2020c). Infeksi COVID19 disertai dengan respons inflamasi agresif dengan pelepasan sejumlah besar sitokin proinflamasi dalam peristiwa yang dikenal sebagai "badai sitokin." Respon imun pejamu terhadap virus SARS-CoV-2 bersifat hiperaktif yang mengakibatkan reaksi inflamasi yang berlebihan. Beberapa studi menganalisis profil 
sitokin dari COVID-19 pasien menyarankan bahwa badai sitokin berkorelasi langsung dengan cedera paru, kegagalan multi-organ, dan prognosis yang kurang baik dari COVID-19 yang parah (Gao et al., 2020; Ruan, Yang, Wang, Jiang, \& Song, 2020; Sun et al., 2020).

Sistem kekebalan memiliki mekanisme luar biasa yang mampu merespons berbagai patogen. Respon imun anti-virus yang normal memerlukan aktivasi jalur inflamasi dari sistem imun; Namun, respon menyimpang atau berlebihan dari sistem kekebalan inang dapat menyebabkan penyakit yang parah jika tidak terkendali (Braciale \& Hahn, 2013). Sitokin adalah bagian penting dari proses inflamasi. Sitokin diproduksi oleh beberapa sel imun termasuk makrofag, sel dendritik, sel Natural Killer (NK) dan limfosit T dan B.

Pattern Recognition Receptor (PRR), adalah receptor pengenalan pola yang mengenali struktur molekul yang berbeda yang merupakan karakteristik virus yang menyerang. Struktur molekul ini disebut sebagai pola molekuler terkait patogen atau disebut Patogen Associated Moleculer Patern (PAMPs). Pengikatan PAMP ke PRR memicu dimulainya respons inflamasi terhadap virus yang menyerang yang mengakibatkan aktivasi beberapa jalur pensinyalan dan selanjutnya faktor transkripsi yang menginduksi ekspresi gen yang bertanggung jawab untuk produksi beberapa produk yang terlibat dalam respons imun inang terhadap virus, di antaranya adalah gen yang mengkode beberapa sitokin pro-inflamasi. Faktor transkripsi utama yang diaktifkan oleh PRR adalah nuclear factor- $k B$, Protein aktivasi1, faktor respons interferon tiga dan tujuh. Faktor transkripsi ini menginduksi ekspresi gen yang mengkode sitokin inflamasi, kemokin, dan molekul adhesi. Urutan kejadian ini menghasilkan perekrutan leukosit dan protein plasma ke tempat infeksi di mana mereka melakukan berbagai fungsi efektor yang berfungsi untuk memerangi pemicu infeksi kemokin dan molekul adhesi. Urutan kejadian ini menghasilkan perekrutan leukosit dan protein plasma ke tempat infeksi di mana mereka melakukan berbagai fungsi efektor yang berfungsi untuk memerangi pemicu infeksi kemokin dan molekul adhesi. Urutan kejadian ini menghasilkan perekrutan leukosit dan protein plasma ke tempat infeksi di mana mereka melakukan berbagai fungsi efektor yang berfungsi untuk memerangi pemicu infeksi (Thompson, Kaminski, Kurt-Jones, \& Fitzgerald, 2011).

Tiga dari sitokin pro-inflamasi yang paling penting dari respon imun bawaan adalah IL-1, TNF- $\alpha$, dan IL-6. Makrofag jaringan, sel mast, endotel, dan sel epitel adalah sumber utama sitokin ini selama respon imun bawaan. "Badai sitokin" dihasilkan dari peningkatan akut yang tiba-tiba dalam tingkat sirkulasi berbagai sitokin pro-inflamasi termasuk IL-6, IL-1, TNF- $\alpha$, dan interferon. Peningkatan sitokin ini mengakibatkan masuknya berbagai sel imun seperti makrofag, neutrofil, dan sel $\mathrm{T}$ dari sirkulasi ke tempat infeksi dengan efek destruktif pada jaringan manusia akibat destabilisasi interaksi sel endotel ke sel, kerusakan sawar pembuluh darah, kerusakan kapiler. kerusakan, kerusakan alveolar difus, kegagalan multiorgan, dan akhirnya kematian (Shimizu, 2019). ARDS yang mengarah ke tingkat saturasi oksigen yang rendah adalah penyebab utama kematian pada COVID-19. Meskipun mekanisme yang tepat dari ARDS di COVID-19 pasien tidak dipahami sepenuhnya, produksi berlebihan dari sitokin pro-inflamasi dianggap salah satu faktor utama (Lai et al., 2020).

Dari berbagai data menunjukkan bahwa beberapa pasien dengan COVID-19 parah menderita "badai sitokin." Analisis kadar sitokin dalam plasma dari 41 kasus terkonfirmasi COVID-19 di China mengungkapkan peningkatan kadar IL-1 $\beta$, IL-7, IL-8, IL-9, IL10 , FGF, G-CSF, GM-CSF, IFN - $\gamma$, IP-10, MCP1, MIP-1A, MIP1-B, PDGF, TNF- $\alpha$, dan VEGF pada pasien yang dirawat di ICU dan non-ICU dibandingkan dengan orang dewasa yang sehat. Semua pasien yang termasuk dalam penelitian ini menderita pneumonia dan $1 / 3$ pasien dirawat di ICU dan enam dari pasien ini meninggal (Huang et al., 2020).

Sebuah studi retrospektif multisenter terhadap 150 pasien COVID-19 di China mengevaluasi prediktor kematian untuk 
COVID-19. Studi ini menganalisis data dari 82 kasus yang sembuh dari COVID-19 dan 68 kasus yang meninggal karena COVID-19 dan melaporkan tingkat IL-6 yang jauh lebih tinggi dalam kasus kematian daripada kasus yang sembuh (Ruan et al., 2020). Studi lain menganalisis data dari 21 pasien di Cina melaporkan peningkatan kadar IL-10, IL-6, dan TNF- $\alpha$ pada kasus yang parah ( $\mathrm{n}=11$ pasien) dibandingkan dengan kasus sedang $(\mathrm{n}=10$ pasien). Sebuah studi serupa oleh Gao et al. menilai 43 pasien di Cina dan melaporkan bahwa kadar IL-6 secara signifikan lebih tinggi pada kasus berat $(\mathrm{n}=15)$ dibandingkan pada kasus ringan ( $\mathrm{n}=28)$ (Gao et al., 2020). Demikian pula, Chen et al. mempelajari total 29 pasien COVID19, dibagi menjadi tiga kelompok sesuai dengan kriteria diagnostik yang relevan, dan menemukan bahwa IL-6 lebih tinggi pada kasus kritis ( $\mathrm{n}=5$ pasien) daripada pada kasus yang parah ( $\mathrm{n}=9$ pasien) dan bahwa IL -6 lebih tinggi pada kasus berat daripada kasus ringan $(n=15$ kasus). Belum banyak data yang tersedia mengenai pasien COVID-19 pediatrik yang parah. Sebuah studi yang mengevaluasi delapan pasien anak COVID-19 yang kritis dan dirawat di ICU, dengan usia berkisar 2 bulan sampai 15 tahun, melaporkan peningkatan tingkat IL-6, IL10 , dan IFN- $\gamma$ (Sun et al., 2020).

Cytokine storm (CS) adalah kondisi kritis yang mengancam jiwa yang membutuhkan perawatan intensif dan memiliki angka kematian yang cukup tinggi. CS ditandai dengan presentasi klinis peradangan sistemik yang luar biasa, hiperferitinemia, ketidakstabilan hemodinamik, dan kegagalan multi-organ, dan jika tidak diobati, hal itu menyebabkan kematian. Pemicu CS adalah respon imun yang tidak terkendali yang mengakibatkan aktivasi dan perluasan sel imun, limfosit, dan makrofag yang terus menerus, yang menghasilkan sejumlah besar sitokin, yang mengakibatkan badai sitokin. Temuan klinis CS dikaitkan dengan aksi sitokin proinflamasi seperti IL-1, IL-6, IL-18, IFN- $\gamma$, dan TNF- $\alpha$ (Shimizu, 2019).

CS telah dilaporkan pada beberapa infeksi virus termasuk virus influenza H5N1 (Ishikawa, 2012; Kalaiyarasu et al., 2016), virus influenza H1N1 (Woo et al., 2010), dan dua coronavirus yang sangat terkait dengan COVID-19; "SARSCoV" dan "MERS-CoV" (Channappanavar \& Perlman, 2017; Lau et al., 2013). Baik sitokin pro-inflamasi (misalnya, IL-1, IL-6, dan TNF- $\alpha$ ) dan sitokin anti-inflamasi (misalnya, antagonis reseptor IL-10 dan IL-1) meningkat dalam serum pasien CS. Kontributor utama interaksi badai sitokin adalah IL-6 dan TNF- $\alpha$. Dengan tidak adanya intervensi terapeutik segera dan tepat, pasien jatuh ke dalam kondisi ARDS sebagai akibat dari kerusakan paru-paru akut diikuti oleh kegagalan multi-organ dan mengakibatkan kematian. Oleh karena itu, CS harus segera diobati, jika tidak dapat mengakibatkan kematian (Ishikawa, 2012). Selain terapi antivirus yang dapat langsung menargetkan virus, terapi antiinflamasi yang mengurangi respons sitokin disarankan untuk menurunkan morbiditas dan mortalitas pada pasien COVID19.

\section{Pengenalan Awal CS dan Pengobatan}

Penanganan yang tepat dapat menghasilkan hasil yang lebih baik. Beberapa agen biologis yang menargetkan sitokin telah diusulkan untuk mengobati CS. Antagonis reseptor IL-1, anakinra, yang digunakan dalam pengobatan rheumatoid arthritis, terbukti membantu dalam panniculitis histiositik sitofagik dengan limfohistiositosis hemofagositik sekunder, penyakit yang berhubungan dengan CS berat (Behrens, Kreiger, Cherian, \& Cron, 2006). Tocilizumab adalah antagonis reseptor IL-6 rekombinan yang mengganggu pengikatan IL-6 pada reseptornya dan memblokir pensinyalan. Tocilizumab digunakan dalam pengobatan rheumatoid arthritis, arthritis idiopatik remaja, arteritis sel raksasa, dan telah terbukti bermakna dalam pengobatan CS. Inhibitor sitokin, misalnya, inhibitor JAK, juga sedang dieksplorasi dalam mengobati CS.

Karena IL-6 adalah sitokin yang paling sering dilaporkan meningkat pada pasien COVID-19 dan karena peningkatan kadar IL-6 telah dikaitkan dengan kematian yang lebih tinggi, tocilizumab adalah obat kandidat untuk digunakan dalam mengelola badai sitokin yang menyertai COVID-19. Hasil yang menggembirakan telah dilaporkan di China di 
mana tocilizumab digunakan dalam pengobatan 21 pasien dengan COVID-19 yang parah dan kritis. Data klinis menunjukkan bahwa gejala, hipoksigenmia, dan perubahan opasitas CT membaik segera setelah pengobatan dengan tocilizumab pada sebagian besar pasien, menunjukkan bahwa tocilizumab dapat menjadi agen terapi yang efisien untuk pengobatan badai sitokin yang terkait dengan COVID-19 (H. Chen et al., 2019). Badan Pengawas Obat dan Makanan AS (FDA) telah menyetujui uji klinis Fase III Roche tentang penggunaan tocilizumab pada pasien rawat inap dengan pneumonia COVID-19 yang parah. Uji coba tersebut rencananya akan melibatkan 330 pasien dengan pneumonia COVID-19 berat (Xu et al., 2020).

\section{KESIMPULAN}

Badai sitokin menjadi salah satu penyebab umum kematian dalam pandemi COVID-19. Pendekatan terapeutik untuk mengelola badai sitokin COVID-19 dapat memberikan jalan untuk mengurangi morbiditas dan mortalitas terkait COVID-19 dan merupakan fokus penelitian yang akan datang.

\section{DAFTAR PUSTAKA}

Bai, Y., Yao, L., Wei, T., Tian, F., Jin, D.-Y., Chen, L., \& Wang, M. (2020). Presumed Asymptomatic Carrier Transmission of COVID-19. JAMA, 323(14), 1406. https://doi.org/10.1001/jama.2020.2565

Behrens, E. M., Kreiger, P. A., Cherian, S., \& Cron, R. Q. (2006). Interleukin 1 receptor antagonist to treat cytophagic histiocytic panniculitis with secondary hemophagocytic lymphohistiocytosis. The Journal of Rheumatology, 33(10), 20812084.

Braciale, T. J., \& Hahn, Y. S. (2013). Immunity to viruses. Immunological Reviews, 255(1), 5-12. https://doi.org/10.1111/imr.12109

Channappanavar, R., \& Perlman, S. (2017). Pathogenic human coronavirus infections: causes and consequences of cytokine storm and immunopathology. Seminars in Immunopathology, 39(5), 529-539. https://doi.org/10.1007/s00281-017-0629$\mathrm{x}$

Chen, H., Wang, F., Zhang, P., Zhang, Y.,
Chen, Y., Fan, X., ... He, A. (2019).

Management of cytokine release syndrome related to CAR-T cell therapy.

Frontiers of Medicine, 13(5), 610-617. https://doi.org/10.1007/s11684-019-07148

Chen, N., Zhou, M., Dong, X., Qu, J., Gong, F., Han, Y., ... Zhang, L. (2020).

Epidemiological and clinical characteristics of 99 cases of 2019 novel coronavirus pneumonia in Wuhan, China: a descriptive study. The Lancet, 395(10223), 507-513.

https://doi.org/10.1016/S01406736(20)30211-7

Dong, Y., Mo, X., Hu, Y., Qi, X., Jiang, F., Jiang, Z., \& Tong, S. (2020).

Epidemiology of COVID-19 Among Children in China. Pediatrics, 145(6). https://doi.org/10.1542/peds.2020-0702

Gao, Y., Li, T., Han, M., Li, X., Wu, D., Xu, Y., ... Wang, L. (2020). Diagnostic utility of clinical laboratory data determinations for patients with the severe COVID-19. Journal of Medical Virology, 92(7), 791796. https://doi.org/10.1002/jmv.25770

Gu, J., Han, B., \& Wang, J. (2020). COVID-19: Gastrointestinal Manifestations and Potential Fecal-Oral Transmission. Gastroenterology, 158(6), 1518-1519. https://doi.org/10.1053/j.gastro.2020.02.0 54

Guo, Y.-R., Cao, Q.-D., Hong, Z.-S., Tan, Y.Y., Chen, S.-D., Jin, H.-J., ... Yan, Y. (2020). The origin, transmission and clinical therapies on coronavirus disease 2019 (COVID-19) outbreak - an update on the status. Military Medical Research, 7(1), 11. https://doi.org/10.1186/s40779020-00240-0

Huang, C., Wang, Y., Li, X., Ren, L., Zhao, J., Hu, Y., ... Cao, B. (2020). Clinical features of patients infected with 2019 novel coronavirus in Wuhan, China. The Lancet, 395(10223), 497-506. https://doi.org/10.1016/S01406736(20)30183-5

Ishikawa, T. (2012). Clinical Preparedness for Cytokine Storm Induced By the Highly Pathogenic H5N1 Influenza Virus. Journal of Pharmacogenomics \& Pharmacoproteomics, 03(06). https://doi.org/10.4172/2153$0645.1000 \mathrm{e} 131$

Kalaiyarasu, S., Kumar, M., Senthil Kumar, D., Bhatia, S., Dash, S. K., Bhat, S., ... 
Nagarajan, S. (2016). Highly pathogenic avian influenza $\mathrm{H} 5 \mathrm{~N} 1$ virus induces cytokine dysregulation with suppressed maturation of chicken monocyte-derived dendritic cells. Microbiology and Immunology, 60(10), 687-693. https://doi.org/10.1111/1348-0421.12443

Lai, C.-C., Shih, T.-P., Ko, W.-C., Tang, H.-J., \& Hsueh, P.-R. (2020). Severe acute respiratory syndrome coronavirus 2 (SARS-CoV-2) and coronavirus disease2019 (COVID-19): The epidemic and the challenges. International Journal of Antimicrobial Agents, 55(3), 105924. https://doi.org/10.1016/j.ijantimicag.2020. 105924

Lau, S. K. P., Lau, C. C. Y., Chan, K.-H., Li, C. P. Y., Chen, H., Jin, D.-Y., ... Yuen, K.Y. (2013). Delayed induction of proinflammatory cytokines and suppression of innate antiviral response by the novel Middle East respiratory syndrome coronavirus: implications for pathogenesis and treatment. Journal of General Virology, 94(12), 2679-2690. https://doi.org/10.1099/vir.0.055533-0

Le, H. T., Nguyen, L. V, Tran, D. M., Do, H. T., Tran, H. T., Le, Y. T., \& Phan, P. H. (2020). The first infant case of COVID-19 acquired from a secondary transmission in Vietnam. The Lancet Child \& Adolescent Health, 4(5), 405-406. https://doi.org/10.1016/S23524642(20)30091-2

Li, S., Jiang, L., Li, X., Lin, F., Wang, Y., Li, B., ... Zhao, J. (2020). Clinical and pathological investigation of patients with severe COVID-19. JCI Insight, 5(12). https://doi.org/10.1172/jci.insight. 138070

Liu, Y., Du, X., Chen, J., Jin, Y., Peng, L., Wang, H. H. X., ... Zhao, Y. (2020). Neutrophil-to-lymphocyte ratio as an independent risk factor for mortality in hospitalized patients with COVID-19. Journal of Infection, 81(1), e6-e12. https://doi.org/10.1016/j.jinf.2020.04.002

Ruan, Q., Yang, K., Wang, W., Jiang, L., \& Song, J. (2020). Correction to: Clinical predictors of mortality due to COVID-19 based on an analysis of data of 150 patients from Wuhan, China. Intensive Care Medicine, 46(6), 1294-1297. https://doi.org/10.1007/s00134-02006028-z

Shimizu, M. (2019). Clinical Features of Cytokine Storm Syndrome. In Cytokine
Storm Syndrome (pp. 31-41). https://doi.org/10.1007/978-3-030-220945_3

Singhal, T. (2020). A Review of Coronavirus Disease-2019 (COVID-19). The Indian Journal of Pediatrics, 87(4), 281-286. https://doi.org/10.1007/s12098-02003263-6

Sun, D., Li, H., Lu, X.-X., Xiao, H., Ren, J., Zhang, F.-R., \& Liu, Z.-S. (2020). Clinical features of severe pediatric patients with coronavirus disease 2019 in Wuhan: a single center's observational study. World Journal of Pediatrics, 16(3), 251-259. https://doi.org/10.1007/s12519-02000354-4

Thompson, M. R., Kaminski, J. J., Kurt-Jones, E. A., \& Fitzgerald, K. A. (2011). Pattern Recognition Receptors and the Innate Immune Response to Viral Infection. Viruses, 3(6), 920-940. https://doi.org/10.3390/v3060920

WHO. (2020a). Laporan Situasi Novel Coronavirus (2019-nCoV) 1. Retrieved April 1, 2020, from https://www.who.int/ website:

https://www.who.int/docs/defaultsource/coronaviruse/situationreports/20200121-sitrep-1-2019ncov.pdf?sfvrsn=20a99c10_4

WHO. (2020b). Laporan Situasi Novel Coronavirus (2019-nCoV) 22.

WHO. (2020c). Laporan Situasi Penyakit Coronavirus 2019 (COVID-19) 127.

WHO. (2020d). Penyakit Coronavirus 2019 (COVID-19) Laporan Situasi 52.

Woo, P. C. Y., Tung, E. T. K., Chan, K., Lau, C. C. Y., Lau, S. K. P., \& Yuen, K. (2010). Cytokine Profiles Induced by the Novel Swine-Origin Influenza A/H1N1 Virus: Implications for Treatment Strategies. The Journal of Infectious Diseases, 201(3), 346-353. https://doi.org/10.1086/649785

Xu, X., Han, M., Li, T., Sun, W., Wang, D., Fu, B., ... Wei, H. (2020). Effective treatment of severe COVID-19 patients with tocilizumab. Proceedings of the National Academy of Sciences, 117(20), 10970 10975. https://doi.org/10.1073/pnas.2005615117

Zhao, S., Zhuang, Z., Ran, J., Lin, J., Yang, G., Yang, L., \& He, D. (2020). The association between domestic train transportation and novel coronavirus (2019-nCoV) outbreak in China from 
2019 to 2020: A data-driven correlational report. Travel Medicine and Infectious Disease, 33, 101568.

https://doi.org/10.1016/j.tmaid.2020.1015 68

Zhou, F., Yu, T., Du, R., Fan, G., Liu, Y., Liu, Z., ... Cao, B. (2020). Clinical course and risk factors for mortality of adult inpatients with COVID-19 in Wuhan, China: a retrospective cohort study. The Lancet, 395(10229), 1054-1062. https://doi.org/10.1016/S01406736(20)30566-3

Zhou, P., Yang, X.-L., Wang, X.-G., Hu, B., Zhang, L., Zhang, W., ... Shi, Z.-L. (2020). A pneumonia outbreak associated with a new coronavirus of probable bat origin. Nature, 579(7798), 270-273. https://doi.org/10.1038/s41586-020-20127 